\title{
Kadar Glukosa Darah Penderita Tuberkulosis Paru dengan Bakteri Tahan Asam Positif
}

\section{Blood Glucose Levels in Patients with Lung Tuberculosis with Positive Acid Resistant Bacteria \\ SUHARYATI \\ S. Y DIDIK WIDIYANTO}

\author{
Jurusan Analis Kesehatan Poltekkes Kemenkes Semarang \\ Jl. Wolter Monginsidi Pedurungan Tengah Semarang \\ E-mail: sy.didik@yahoo.co.id
}

\begin{abstract}
Abstrak
Tuberkulosis paru adalah penyakit menular yang disebabkan oleh Mycobakterium tuberculosis, penyakit Diabetes melitus merupakan salah satu faktor resiko tersering pada penderita tuberkulosis paru, perlangsungan TB Paru-DM lebih berat dan kronis dibanding non diabetes, yang mana dapat mengakibatkan meningkatnya kerentanan terhadap bakteri tuberkulosis dan waktu pengobatan yang lama. Tujuan penelitian ini untuk mengetahui gambaran glukosa darah pada penderita tuberkulosis paru positif di UP3 Kebumen. Metode penelitian yang dilakukan termasuk jenis penelitian deskriptif. Populasi penelitian adalah semua pasien tuberkulosis paru dengan BTA positif di UP3 Kebumen tahun 2017. Sampel yang digunakan berjumlah 100 sampel, 6 sampel mempunyai kadar glukosa darah $\geq 200$ $\mathrm{mg} / \mathrm{dl}, 4$ orang kadar glukosa darah antara $150-199 \mathrm{mg} / \mathrm{dl}$, dan paling banyak mempunyai kadar glukosa darah antara $70-149 \mathrm{mg} / \mathrm{dl}$. Kesimpulan dari penelitian ini adalah penderita tuberkulosis paru di UP3 Kebumen hanya sebagian kecil yang menderita Diabetes.
\end{abstract}

Kata Kunci: Kadar Glukosa Darah ; Tuberkulosis Paru

\begin{abstract}
Pulmonary Tuberculosis is an infectious disease caused by Mycobacterium tuberculosis, Diabetes Mellitus is one of the most common risk factors in pulmonary tuberculosis patients. Pulmonary TB - DM is more severe and chronic than non-diabetic, which can lead to increased susceptibility to tuberculosis bacteria and longer treatment times. Purpose paper's is knowing the picture of blood glucose in positive pulmonary tuberculosis patients in UP3 Kebumen. The research conducted included descriptive research type. The population of this study were all pulmonary tuberculosis patients with positive smear in UP3 Kebumen in 2017. The sample used was 100 samples, 6 samples had blood glukosa levels $\geq 200 \mathrm{mg} / \mathrm{dl}$, and as many as 4 people blood glukosa levels between 150 - $199 \mathrm{mg} / \mathrm{dl}$. And most have blood glukosa levels between $70-149 \mathrm{mg} / \mathrm{dl}$. Pulmonary TB sufferers in UP3 Kebumen are only a few who suffer from Diabetes.
\end{abstract}

Keyword: Blood Glucose Level ; Pulmonary Tuberculosis

\section{Pendahuluan}

Tuberkulosis (TB) dikenal sebagai pembunuh utama di antara penyakit infeksi bakterial di dunia. Penyakit ini disebabkan oleh kuman Mycobakterium tuberculosis, yang berbentuk batang bersifat aerob dan tahan asam. Menurut World Health Organisation (WHO) 2013, 
Indonesia menempati peringkat empat setelah India, China dan Afrika Selatan sebagai negara dengan insidensi TB tertinggi di dunia. Berdasarkan data Riskesdas 2013 prevalensi penduduk dengan gejala TB paru batuk $\geq 2$ minggu sebesar 3,9\% dan batuk darah sebesar $2,8 \%$.

Menurut Wijaya (2015) terdapat beberapa kendala dalam penanganan kasus TB Paru saat ini. Kendala utama yang ditemukan adalah adanya peningkatan kasus DM. Diabetes Militus (DM) merupakan suatu penyakit menahun yang ditandai oleh kadar glukosa darah melebihi normal serta gangguan metabolisme karbohidrat, lemak, dan protein yang disebabkan oleh kekurangan hormon insulin secara relatif. Pada umumnya ada 2 tipe diabetes, yaitu diabetes tipe 1 (tergantung insulin), dan diabetes tipe 2 (tidak tergantung insulin), tetapi ada pula diabetes dalam kehamilan yang biasa disebut diabetes gastointestinal. Kasus diabetes dilaporkan mengalami peningkatan di berbagai negara berkembang termasuk di Indonesia (Suyono, 2009).

Menurut Worid Health Organitation (WHO) pada tahun 2012, jumlah penderita DM mencapai 194 juta jiwa dan diperkirakan meningkat menjadi 333 juta jiwa di tahun 2025 mendatang, dan setengah dari angka tersebut terjadi di negara berkembang, termasuk negara Indonesia. Angka kejadian DM di Indonesia menempati urutan keempat tertinggi di dunia yaitu 8,4 juta Jiwa. Jumlah penderita DM meningkat akibat faktor genetik, pola hidup yang tidak sehat, prevalensi obesitas meningkat dan kurangnya kegiatan fisik atau olahraga. Angka kejadian DM menurut data Riskesdas (2013) terjadi peningkatan dari 1,1\% di tahun 2007 meningkat menjadi 2,1\% di tahun 2013 dari keseluruhan penduduk sebanyak 250 juta jiwa.

Peningkatan prevalensi data penderita DM salah satunya yaitu Provinsi Jawa Tengah yang mncapai 152.075 kasus. Dinas Kesehatan Kabupaten Kebumen pada tahun 2015 penderita DM sebanyak 2.216 kasus.

Diabetes Militus (DM) merupakan salah satu faktor risiko tersering pada pasien TB paru. Saat ini, prevalensi terjadinya TB paru meningkat seiring dengan peningkatan prevalensi pasien DM.

\section{Metode}

Penelitian karya tulis ilmiah ini merupakan penelitian observasional deskriptif dengan tujuan untuk mengetahui gambaran kadar glukosa darah pada penderita Tuberkulosis paru dengan Bakteri Tahan Asam positif di UP3 Kebumen pada bulan Mei sd Juli 2018 dengan mengambil data TB 01 dari bulan Januari sd Desember 2017, Register Laboratorium kadar glukosa dan Profil UP3 tahun 2017. Selanjutnya data yang diperoleh dari pemeriksaan laboratorium disajikan dalam bentuk diagram pie yang dikelompokkan berdasarkan umur, jenis kelamin dan kadar glukosa darah.

\section{Hasil dan Pembahasan}

Penderita TB paru dengan BTA positif terbanyak adalah dari golongan yang berusia 45-54 tahun yaitu sebanyak 26 orang (26\%). Jumlah ini tidak jauh beda dengan kelompok kedua dan ketiga tertinggi yang menderita TB paru yaitu kelompok usia 15-24 tahun yaitu sebanyak 22 orang (22\%) dan usia 45-54 tahun sebanyak 18 orang (18\%).Hasil ini dapat didukung oleh data epidemiologi TB paru di Indonesia oleh WHO dimana kasus tertinggi TB per 100.000 populasi pada tahun 2007 adalah pada kelompok 55-64 tahun (310 orang), diikuti kelompok usia 45-54 (250 orang), dan seterusnya 35-44 tahun (190 orang) dan 25-34 tahun (200 orang). Hal ini karena kombinasi daripada peningkatan resiko infeksi apabila seseorang individu meningkat dewasa menjadi lebih independen, banyak kegiatan diluar rumah dan lebih bergaul dalam masyarakat (P.D.O Davis, 2005).

Kasus TB paru lebih tinggi pada jenis kelamin laki-laki yaitu sebanyak 65 orang (65\%) dibanding perempuan yaitu sebanyak 35 orang (35\%). Hasil ini didukung oleh data epidemiologi TB paru di Indonesia oleh WHO dimana pada kasus TB per 100.000 populasi pada tahun 2007 kasuslaki-laki lebih tinggi terinfeksi TB paru dibandingkan perempuan. 
Perbedaan ini dapat dilihat mulai usia 15 -24 tahun dan seterusnya. Kasus TB pada laki-laki lebih banyakkarena laki-laki sering merokok dimana faktor ini merupakan resiko untuk infeksi TB paru. Kasus laki-laki usia lebih tua adalah 3 kali lipat dibandingkan pada perempuan (P.D.O Davis, 2005).

Jumlah penderita yang didiagnosa penyakit Tuberkulosis paru dengan BTA positifdi UP3 Kebumen Tahun 2017 cukup tinggi sebanyak 100 orang. Faktor-faktor yang dapat menyumbang kepada infeksi TB paru adalahdaya tahan yang menurun,negara dengan kasus TB tinggi dan sebagainya. Indonesia sendiri boleh dikatakan merupakan salah satu negara yang kasus TB masih tinggi. Menurut Sanusi (2006), penelitian TB paru pada DM di Indonesia masih cukup tinggi yaitu antara $12,8-42 \%$ dan bila dibanding dengan luar negeri maka prevalensidi Indonesia masih cukup tinggi.

Pada Tahun 2017 di UP3 Kebumen sebanyak 6 orang (6\%) dari 100 orang penderita TB paru dengan BTA positif tercatat mempunyai kadar glukosa darah $\geq 200 \mathrm{mg} / \mathrm{dl}$. Hasil ini sama dengan penelitian terbaru dari Institut Daerah Medikal Sciences, Imphal-India, (2009) prevalensi TB paru pada penderita DM ditemukan 27\% dengan diagnosis radiologi dan $6 \%$ dengan positif dahak. Jumlah ini walaupun kecil punya peranan dan menunjukkan adanya hubungan antara infeksi TB paru dengan riwayat menderita diabetes melitus.

Hasil gambaran kadar glukosa darah ini juga dapat menentukan pengobatan TB paru selanjutnya, seperti menurut buku Tata Laksana Tuberkulosis (2013) panduan pengobatan TB dengan diabetes melitus pada dasarnya sama dengan TB tanpa DM, dengan syarat kadar glukosa darah terkontrol, apabila kadar gula darah tidak terkontrol, maka lama pengobatan dapat dilanjutkan sampai 9 bulan. Di Unit Pengobatan Penyakit Paru Kebumen penderita TB paru dengan kadar $\geq 200 \mathrm{mg} / \mathrm{dl}$ mendapat pengobatan TB sampai 9 bulan dan melakukan kontrol rutin kadar glukosanya.

\section{Simpulan dan Saran}

\section{Simpulan}

Dari penelitian ini dapat disimpulkan bahwa gambaran kadar glukosa darah pada penderita tuberkulosis paru dengan bakteri tahan asam positifdi Unit Pengobatan Penyakit Paru Kebumen Tahun 2017 yang mempunyai kadar glukosa darah tinggi $\geq 200 \mathrm{mg} / \mathrm{dl}$ ada 6 orang $(6 \%), 4$ orang $(4 \%)$ adalah merupakan pasien yang mempunyai gangguan toleransi glukosa antara 151 hingga $199 \mathrm{mg} / \mathrm{dl}$, dan 90\% lagi mempunyai kadar glukosa darah dalam batas normal $(70-150 \mathrm{mg} / \mathrm{dl})$. Penderita TB paru paling banyak adalah dari kelompok umur yang berusia 45-54 tahun yaitu sebanyak 26 orang (26\%), dan diikuti kelompok kedua dan ketiga yang tinggi pada usia 15-24 tahun sebanyak 22 orang (22\%) dan kelompok usia 46-54 tahun sebanyak 18 orang (18\%). Kasus TB paru lebih tinggi pada jenis kelamin laki-laki yaitu sebanyak 65 orang (65\%) dibandingkan perempuan sebanyak 35 orang $(35 \%)$.

\section{Saran}

Diharapkan selanjutnya diadakan penelitian lebih lanjut tentang mengkaji faktor-faktor lain yang menjadi penyebab kepada terjadinya penyakit TB paru seperti hubungan yang terkait rapat dengan kadar glukosa darah.

\section{Daftar Pustaka}

Alfath, Depkes RI. 2008. Pedoman Nasional Penanggulangan Tuberculosis, Jakarta: Depkes RI

Kemenkes, RI. 2014. Pedoman Nasional Penanggulangan Tuberculosis. Jakarta: Direktorat Jenderal Pengendalian Penyakit dan Penyehatan Lingkungan.

Kemenkes, RI. 2014. Pedoman Nasional Pelayanan Kedokteran Tata Laksana Tuberculosis. Jakarta: Kementerian Kesehatan RI 
Mario, R. C., and Richard, O, J. 2008. Section 8: Mycobacterial Disease. In: Fauci, Braunwald, Kasper, Hauser, Longo, Jameson, Loscalzo, ed., Harrison,s Principle of Internal Medicine, 17 th ed. VS: Mc Grow Hill, 106.

Perkeni. Pengelolaan dan Pencegahan Diabetes Militus Tipe 2 di Indonesia. Jakarta: PB Perkeni; 2011

P.D.O. Davies, 2005. Risk factors for Tuberculosis, UK. Available from : http://archest.fsm.it/pne/pdf/63/1/pne63-1_06davies.pdf (accesed 13November 2010)

Smeltzer, Luzune C. Dan Bare, Brenda G, 2002, Buku Ajar Keperawatan Medical Bedah Brunner dan Saddarh (Ed.8 vol. 1,2), Jakarta

Sanusi, H. 2006. Diabetes Melitus dan Tuberkulosis Paru, Makassar. Available from : $\mathrm{http}: / /$ med.unhas.ac.id/index.php?option=com_content\&task=view\&id=154\&Itemid=7\& limit $=1 \&$ limitstart $=2$ (Accesed 2 May 2010)

Wijaya, I, 2015. Tuberculosis Paru Pada Penderita Diabetes Melitus. CDK-229/vol. 42 no. 6, th. 2015. Tangerang: Departemen Penyakit Dalam Fakultas Kedokteran Universitas Pelita Harapan. (Sitasi: 16 Februari 2017)

Wahid dan Suprapto, 2014. Dokumentasi Proses Keperawatan. Yogyakarta: Nuha Medika

Word Health Organization. Global Tubercolosis Control: 2010. Geneva: WHO; 2010

Zhang, Q., Xiao, H., \& Sugawara, I., 2009. Tuberculosis Complicated by Diabetes Mellitus at Shanghai Pulmonary Hospital, China. 